\title{
Congenital cardiac abnormalities in monozygotic twins Report and review of the literature
}

\author{
STUART F. SEIDES, RICHARD J. SHEMIN, AND ANDREW G. MORROW \\ From the Cardiology and Surgery Branches, National Heart, Lung, and Blood Institute, \\ National Institutes of Health, Bethesda, Maryland, USA
}

SUMMARY A pair of monozygotic twin girls is reported with concordance for 3 congenital cardiac abnormalities: (1) secundum atrial septal defect, (2) aneurysm of the membraneous ventricular septum, and (3) electrocardiographic frontal plane left axis deviation.

A review of the published materials shows a 9.5 per cent incidence of concordance for congenital heart disease among monozygotic twins. In those in whom a precise cardiological diagnosis was made, $15 / 16$ pairs $(95 \%)$ were concordant for a specific defect, 2 had an additional defect, and only 1 pair had completely dissimilar defects.

Concordance for congenital heart disease in monozygotic twins is uncommon, but when it occurs the defects will most often be identical.

The study of twins can provide information pertinent to the aetiology of congenital heart diseases. Several previous studies have noted the surprising lack of concordance for congenital heart malformations in monozygotic twins (Uchida and Rowe, 1957; Nora et al., 1967; Anderson, 1976). The purpose of this communication is to report a unique pair of monozygotic twins in whom secundum atrial septal defect, aneurysm of the membraneous ventricular septum, and frontal plane electrocardiographic left axis deviation were identified in each patient. This prompted a review of the published reports on the inheritance of congenital heart disease and the specificity of phenotypic expression.

\section{Case report}

J.D. and K. D. were 11-year-old twin girls referred to the National Heart, Lung, and Blood Institute for diagnosis and treatment of congenital heart disease. The patients were products of an uncomplicated, full-term spontaneous vaginal delivery of a gravida 6 , para 6, 34-year-old mother. Both parents were of Southern Italian ancestry. At birth both girls were noted to be small relative to gestational age. Both children achieved normal psychomotor development and were without any non-cardiac developmental anomalies. K. D. was entirely asymptomatic while J. D. began to note dyspnoea on severe exertion 6 months before admission.
Family history revealed that the mother had died suddenly of unknown causes 2 years before admission. The propostii had 7 additional sibs, including a set of fraternal female twins aged 17 years. Non-invasive cardiac evaluation including physical examination, electrocardiogram, chest $x$-ray film, and echocardiogram showed no evidence of heart disease in the fraternal twins, the father, and 5 sibs. Two other sibs were unavailable for examination, but neither had a history of heart disease and both were found fit for military service.

On physical examination the patients were identical in appearance: they weighed $19 \mathrm{~kg}$ and were $127 \mathrm{~cm}$ tall (both in the first centile for age). Monozygosity was further confirmed by the establishment of concordance for 18 red blood cell antigens (calculated probability of monozygosity of greater than 0.99 (Smith and Penrose, 1955)). Arterial pulses and jugular venous pressures were normal. Both children had a parasternal right ventricular lift and only minimal (0.02 s) respiratory variation of a widely split $S_{2}$. K. D. had a grade $3 / 6$ systolic ejection murmur along the left sternal border, and J. D. had a louder, longer, grade $4 / 6$ holosystolic murmur localised to the lower left sternal border. Neither child had physical findings indicative of heart failure. Electrocardiograms (Fig. 1) showed normal sinus rhythm, left axis deviation of $-60^{\circ}$ with a counterclockwise loop in the frontal plane, and an $\mathrm{rSR}^{\prime}$ pattern in lead V1. Chest radiographs revealed mild dilatation of the 
K.D.

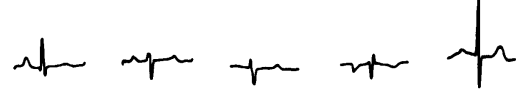

J.D.

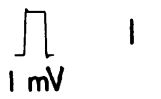

II

AVF

VI

V6

$1 \mathrm{mV}$<smiles>[Mg][I-]</smiles>

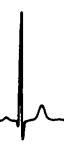

Fig. 1 Selected electrocardiographic leads from twins $K . D$. and F. D., showing left axis deviation in the frontal plane and an rSR' pattern in lead V1.

main pulmonary artery segments and increased pulmonary vascular markings consistent with leftto-right shunt. Cardiac catheterisation showed normal to slightly raised pulmonary arterial pressures (J. D. $35 / 13 \mathrm{mmHg}$, mean $24 \mathrm{mmHg}$; K. D. $28 / 14 \mathrm{mmHg}$, mean $22 \mathrm{mmHg}$ ); other intracardiac pressures were within normal limits. Both children had large left-to-right shunts at the atrial level, as determined by oximetry and dye dilution curves. Pulmonary to systemic flow ratio was $2 \cdot 3$ in J. D. and 3.3 in K. D. Left ventricular cineangiography (Fig. 2) showed opacification of the right ventricle across a small membraneous infracristal ventricular septal defect in J. D. and a small aneurysmal outpouching, with a smooth wall and wide neck in the same region of the ventricular septum without apparent intraventricular communication in K. D.

At operation each patient was found to have an identical, $1 \times 2 \mathrm{~cm}$, secundum atrial septal defect

which was closed with a Teflon patch. In addition, they were found to have had identical aneurysms of the membraneous ventricular septum. In J. D. the aneurysm had a 3-mm diameter opening in its apex which was closed with a single suture. The girls recovered uneventfully from operation. Six months after operation both patients were asymptomatic, and recatheterisation showed normal right heart pressures with no evidence of residual intracardiac shunt.

\section{Discussion}

Both members of the monozygotic twinship described in this report manifested a complex of three essentially identical congenital cardiac abnormalities. The haemodynamically important part of this complex was a secundum atrial septal defect, with a large left-to-right shunt. The second part of the complex was an aneurysm of the membraneous portion of the ventricular septum, which contained a small intraventricular communication in one of the twins (J.D.). Though it is likely that K. D. also had an intraventricular communication through the region of the aneurysm earlier in her course, which closed spontaneously (Varghese et al., 1966), this point remains speculative. The third part of the complex was the finding in the electrocardiogram of frontal plane left axis deviation consistent with the diagnosis of the left anterior hemiblock (Rosenbaum et al., 1970).

The complex represents a rare combination of anomalies. Less than 5 per cent of patients with secundum atrial septal defects are reported to have left axis deviation on the electrocardiogram (Harrison and Morrow, 1963), and less than 10

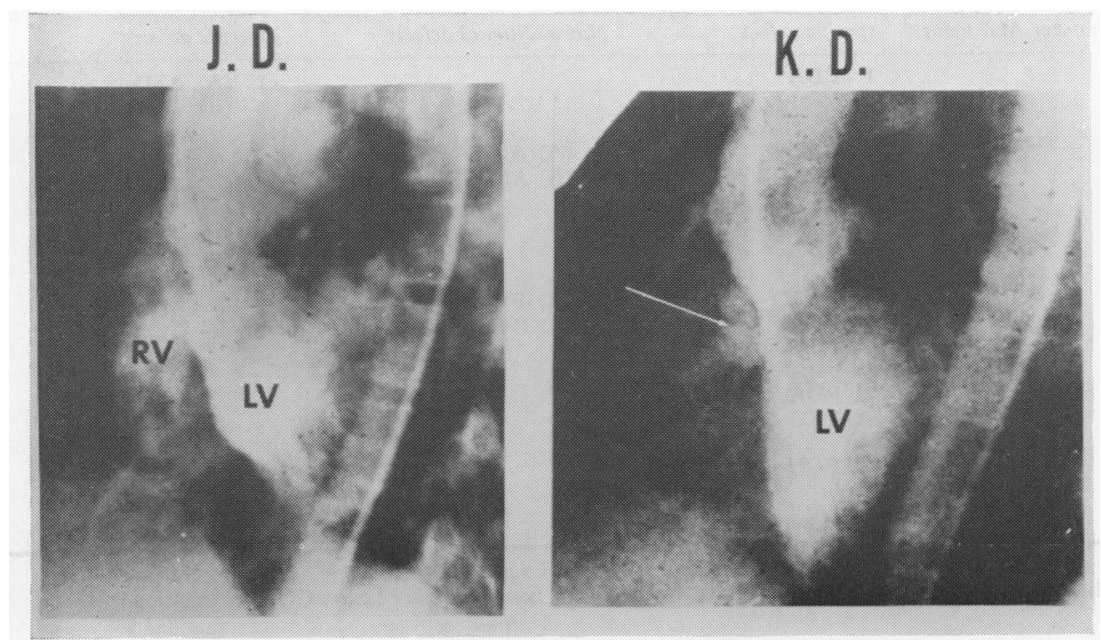

Fig. 2 Left ventricular (LV) cineangiogram in the $70^{\circ}$ left anterior oblique projection showing early opacification of the right ventricle $(R V)$ across a high ventricular septal defect in F. D., and an aneurysm of the ventricular septum (white arrow) without interventricular shunting in K. D. 
per cent of patients with membraneous ventricular septal defect have associated atrial septal defect (Girod et al., 1966).

Table 1 Prevalence of concordance for congenital heart disease in twinships

\begin{tabular}{llll}
\hline Author & Monozygotic & Dizygotic & Total \\
\hline Ross (1959) & $2 / 9$ & $2 / 26$ & $4 / 35$ \\
Nora et al. (1967) & $6 / 13$ & $1 / 24$ & $7 / 37$ \\
Anderson (1977) & $4 / 59$ & $1 / 43$ & $5 / 102$ \\
Kenna et al. (1975) & $2 / 15$ & $2 / 12$ & $4 / 27$ \\
Menashe et al. & $0 / 15$ & 0 & $0 / 15$ \\
$\begin{array}{c}\text { (1967) } \\
\text { Uchida and Rowe }\end{array}$ & $0 / 13$ & $0 / 13$ & $0 / 26$ \\
$\begin{array}{c}\text { (1957) } \\
\text { Lamy et al. (1957) }\end{array}$ & $0 / 7$ & $1 / 9$ & $1 / 16$ \\
Leck et al. (1965) & $0 / \star$ & $1 / *$ & $1 / 22$ \\
Campbell (1961) & $0 / 12$ & $0 / 4$ & $0 / 16$ \\
$\begin{array}{c}\text { Myrianthopoulos } \\
\text { (1975) }\end{array}$ & $1 / 6$ & $0 / 1$ & $1 / 7$ \\
Hay and Wehrung & & & \\
(1970) & $5 / 59$ & $2 / 69$ & $7 / 128$ \\
\hline Total & $20 / 208=9.5 \%$ & $9 / 201=4.5 \%$ & $30 / 431=7 \cdot 0 \%$ \\
\hline
\end{tabular}

* Number $\mathrm{MZ}$ and $\mathrm{DZ}$ twins not reported; number not included in totals.

Despite identical genotype and near identical prenatal environment, the incidence of concordance for congenital heart disease in monozygotic twins is low. Table 1 sets out 11 series representing 208 monozygotic twins and 201 dizygotic twins, selected for the presence of congenital heart disease in one member of the twinship. The prevalence of concordance for any congenital heart disease was 9.5 per cent in the monozygotic twins and 4.5 per cent in the dizygotic twins. Only 5 of the series reported sufficient data to allow an analysis of the specific cardiac defects (Table 2). When a monozygotic twinship was concordant for congenital heart disease, there was a 94 per cent incidence for concordance for the specific defect. While additional defects may be present in a co-twin, only one pair was reported to have completely different defects. Therefore, excluding complex fused hearts, 10/100 $(10 \%)$ of completely diagnosed monozygotic twins were fully (specific defect) concordant.

As emphasised by Nora et al. (1967), the genetics of congenital heart disease rarely conforms to either a typical Mendelian (for example, Hurler's syndrome) or chromosomal (for example trisomy 21) mode of inheritance. Most often the aetiological mechanism appears to be multifactorial, representing an interaction between a genetic threshold of liability and environmental factors of variable potency (Falconer, 1977).

Both the atrial septum secundum and the membraneous ventricular septum are formed in the fifth to seventh week of gestation (Warkany, 1971), with the cardiac specialised conduction system being formed somewhat earlier (Davies, 1971). In the family described here the hereditary predisposition toward congenital heart disease did not appear strong in that none of the remaining 7 children or the father have any known evidence of congenital heart disease. Hence environmental factors may have played an important role in the abnormal prenatal development of these twins.

The authors wish to thank Drs Jeffrey S. Borer, Barry J. Maron, and Stephen E. Epstein for the clinical care and evaluation of these patients.

Table 2 Concordance for specific defects in monozygotic twins with congenital heart disease

\begin{tabular}{|c|c|c|c|c|c|}
\hline Author & $\begin{array}{l}\text { Number concordant with } \\
C H D / \text { mumber } M Z \text { twins }\end{array}$ & & $\begin{array}{l}\text { mber concordant for } \\
\text { cific defect }\end{array}$ & $\begin{array}{l}\text { Number concordant for specific } \\
\text { plus additional defects }\end{array}$ & $\begin{array}{l}\text { Number nonconcordant for } \\
\text { specific defects }\end{array}$ \\
\hline Ross (1959) & $2 / 9$ & 1 & PDA & & $\begin{array}{l}1 \text { (A) ASD } \\
\text { (B) VSD }\end{array}$ \\
\hline Nora et al. (1967) & $6 / 13$ & 5 & $\begin{array}{l}\text { ASD } \\
\text { VSD } \\
\text { TOF } \\
\text { PS } \\
\text { PDA }\end{array}$ & $\begin{array}{l}1 \text { (A) ASD, VSD } \\
\text { (B) ASD, PDA, COA }\end{array}$ & \\
\hline Anderson (1977) & $4 / 59$ & 3 & $\begin{array}{l}\text { HLH } \\
\text { PABS } \\
\text { FCH }\end{array}$ & $\begin{array}{l}1 \text { (A) PVS } \\
\text { (B) PVS, VSD }\end{array}$ & \\
\hline Kenna et al. (1975) & $2 / 15$ & 2 & $\begin{array}{l}\text { PDA } \\
\text { VSD }\end{array}$ & & \\
\hline Myrianthopoulos (1975) & $1 / 6$ & 1 & $\mathbf{F C H}$ & & \\
\hline Total & $15 / 102$ & 12 & & 2 & 1 \\
\hline
\end{tabular}

ASD, atrial septal defect; VSD, ventricular septal defect; PDA, persistent ductus arteriosus; TOF, tetralogy of Fallot; PS, pulmonary stenosis; PABS, pulmonary artery branch stenosis; HLH, hypoplastic left heart; FCH, fused complex heart; COA, coarctation of aorta; MZ, monozygotic; DZ, dizygotic. 


\section{References}

Anderson, R. C. (1976). Fetal and infant death, twinning, and cardiac malformations in families of 2000 children with and 500 without cardiac defects. American fournal of Cardiology, 38, 218-224.

Anderson, R. C. (1977). Congenital cardiac malformations in 109 sets of twins and triplets. American fournal of Cardiology, 39, 1045-1050.

Campbell, M. (1961). Twins and congenital heart disease. Acta Genetica et Statistica Medica, 10, 443-456.

Davies, M. J. (1971). Pathology of Conducting Tissue of the Heart, p. 121. Appleton-Century-Crofts, New York.

Falconer, D. S. (1977). The inheritance of liability to certain diseases, estimated from the incidence among relatives. Annals of Human Genetics, 29, 52-71.

Girod, D. A., Raghib, G., Adams, P., jun, Anderson, R. C., Wang, Y., and Edwards, J. G. (1966). Cardiac malformation associated with ventricular septal defect. American fournal of Cardiology, 17, 73-82.

Harrison, D. C., and Morrow, A. G. (1963). Electrocardiographic evidence of left-axis deviation in patients with defects of the atrial septum of the secundum type. New England fournal of Medicine, 269, 743-745.

Hay, S., and Wehrung, D. A. (1970). Congenital malformations in twins. American fournal of Human Genetics, 9, 662678.

Kenna, A. P., Smithells, R. W., and Fielding, D. W. (1975). Congenital heart disease in Liverpool, 1960-1969. Quarterly Fournal of Medicine, 43, 17-44.

Lamy, M., de Grouchy, J., and Schweisguth, O. (1957). Genetic and non-genetic factors in etiology of congenital heart disease: study of 1188 cases. American fournal of Human Genetics, 9, 17-41.
Leck, I., McKeown, T., and Record, R. G. (1965). Cardiac malformations in a population observed for six years after birth. British fournal of Preventive and Social Medicine, 19, 49-50.

Menashe, V. D., Osterud, H. T., and Griswold, H. E. (1967). Mortality from congenital cardiovascular disease in Oregon. Pediatrics, 40, 334-344.

Myrianthopoulos, N. C. (1975). Congenital malformations in twins: epidemiologic survey. Birth Defects, 11, No 8, 1-39.

Nora, J. J., Gilliland, J. C., and Somerville, R. J. (1967). Congenital heart disease in twins. New England fournal of Medicine, 277, 568-971.

Rosenbaum, M. B., Elizari, M. V., and Lazzari, J. O. (1970). The Hemiblocks, p. 74. Tampa Tracings, Oldsmar, Florida.

Ross, L. J. (1959). Congenital cardiovascular anomalies in twins. Circulation, 20, 327-342.

Smith, S. M., and Penrose, L. S. (1955). Monozygotic and dizygotic twin diagnosis. Annals of Human Genetics, 19, 273-289.

Uchida, I. A., and Rowe, R. D. (1957). Discordant heart anomalies in twins. American fournal of Human Genetics, 9, 133-140.

Varghese, P. J., Izukawa, T., and Celermajer, J. (1966). Aneurysm of the membraneous ventricular septum. American fournal of Cardiology, 24, 531-536.

Warkany, J. (1971). Congenital Malformations, p. 480. Year Book, Chicago.

Requests for reprints to Dr Stuart F. Seides, Greater Southeast Community Hospital, 1310 Southern Avenue, Southeast, Washington, DC 20032, USA. 